\title{
IMPROVING THE HYGIENIC AND CHEMICAL QUALITY OF SILVER CARP FISH USING COMBINED LOW SALT AND IRRADIATION TREATMENTS \\ Afifi, El. A. ${ }^{a}$; H. A. Shawki ${ }^{a}$ and Amira E. A. El-Hanafy ${ }^{b}$ \\ ${ }^{a}$ Nuclear Research Center, Atomic Energy Authority, Egypt. \\ ${ }^{b}$ Central Lab. for Aquaculture Research, Agric. Research Center, Egypt
}

\begin{abstract}
The present study was conducted to evaluated the combined effect of low dose gamma irradiation (1,2,3 and $5 \mathrm{kGy})$ and/or salting (10\% salt solution) on chemical, microbiological and sensory properties of silver carp fish during cold storage at $4{ }^{\circ} \mathrm{C}$ \pm 1 . At periodic intervals, quality of silver carp fish was determined by sensory evaluation (appearance, odor and texture); chemical composition (moisture; protein; fat and ash); freshness index (total volatile bases nitrogen (TVBN); trimethylamine (TMA); thiobarbituric acid (TBA) and $\mathrm{pH}$ ) and microbiological parameters (total bacterial count (TBC); psychrophilic bacteria; enterobacteriaceae and mold and yeast counts. The control sample of silver carp fish was acceptable up to 6 days, in comparison to a storage shelf life of 18,$24 ; 27$ and 30 days for the unsalted fish irradiated at $1,2,3$, and $5 \mathrm{kGy}$, respectively. Salting (brine solution $10 \%$ ) prior to gamma irradiation at $0,1,2,3$ and $5 \mathrm{kGy}$ give a shelf life of $12,18,24,27$ and 30 days, respectively. Salting give a firmer texture to the silver carp fish during cold storage.

It could be concluded that irradiation at $3 \mathrm{kGy}$ can improve the hygienic quality of silver carp fish and enhance shelf life. Dipping in salt solution $(10 \% \mathrm{NaCl})$ prior to irradiation did not have any additional advantage in the shelf life extension of fish by irradiation, other benefits were noted such as: enhanced irradiation-induced elimination of the evaluated microorganisms; improved fish texture during cold storage.
\end{abstract}

\section{INTRODUCTION}

The two major problems with respect to marketing and distribution of seafood's are their high perishability and poor hygienic attributes quality. This is essentially due to contamination of the commodity by spoilage and pathogenic microorganisms (Gram and Huss, 1996 and Garrett, et,al.,1997). Low-doses (1-3) gamma irradiation is a process, which has a potential for the extension of refrigerated shelf life and hygienic of fishery products (Venugopal, et al., 1999).With the observation of the Joint Expert Committee of $\mathrm{FAO} / \mathrm{WHO} / \mathrm{IAEA}$ that irradiation of any food commodity up to an overall average dose of $10 \mathrm{kGy}$ presents no toxicological hazard; there has been worldwide interest in using the technology for conservation of various foods including fishery products (IAEA, 1989; WHO, 1994).Combination of process treatments for food preservation may result in synergistic or cumulative effects of microbiological barriers or hurdles, leading to a reduced level of one or all the treatments (Scott, 1989; Leistner and Gorris, 1995).

Icekson,et al., (1996) used ionizing radiation in combination with refrigeration (0-2C) to extend shelf life of carp (Cyprinus carpio) based on sensory evaluation. They found that shelf life of freshwater carp was extended to31 days for the irradiated fish $\left(1.5 \mathrm{kGy}, 0-2^{\circ} \mathrm{C}\right)$ was obtained for 
Afifi, El. A. et al.

freshwater carp, compared to shelf -life of 15 days for the non irradiated fish.Low-dose irradiation is a barrier, which has the potential for fish preservation when applied in combination with processes such as chilling or heating (Venugopal, et al., 1999).

Salting is a common food processing operation which is known to preserve wet fishery products (Sofos, 1984), improve their texture (Ingram and Kitchell, 1967), and enhances their water holding capacity (Regenstein, et al., 1984; Sofos 1984).

Fu, et al.,(1995) observed a sensitizing effect of salt on irradiation induced reduction of total plate count including pathogens in cooked pork chops and cured ham.

The study presented here was conducted to determine the additional benefits of the combination treatment between salting and irradiation with different low doses on the preservation of silver carp fish using chemical, microbiological and sensory evaluations.

\section{MATERIALS AND METHODS}

Fresh raw material:

Silver carp (hypophthalmichthys molitrix) were obtained from the production pond of the Central Laboratory for Aquaculture Research, Abbassa, Abu-Hammad, El-sharkia Governorate in February 2006. The length of the fish ranged between $36.3-42.5 \mathrm{~cm}(39.4 \mathrm{~cm})$ and the weight ranged between 800-1300 (1050 gm), fish was transported directly after catching in ice boxes to the laboratory of fish processing and quality control for washing and eviscerating then washing again for removing the remaining slime; scales; blood and adhering viscera tissue etc., divided into three part: control, salt treated and irradiated

- Salt treated fish: The second part of fish was immersed in cold $\mathrm{NaCl}$ brine $10 \%(\mathrm{w} / \mathrm{w})$ at $10{ }^{\circ} \mathrm{C} \pm 1$ for $1 \mathrm{~h}$. and salted fish divided into 2 parts one as salted fish only and the other was subjected to gamma irradiation with 1,2,3, and 5 kGy.

Thereafter, all fish samples were packaged in polyethylene bags and tightly sealed and transported to Food irradiation Laboratory, Plant Research Dept., Radioisotope Application Division, Nuclear Research Center, Abu Zaabal, Egypt, for irradiation process and analysis.

- Irradiated fish:

The third part of fish was exposed to gamma irradiation with 1, 2, 3 and 5 kGy at Cobalt-60 Egypt's Industrials Mega Gamma irradiator of NCRRT. The dose rate was $0.6 \mathrm{kGy} / \mathrm{hour}$.

- Cold storage:

Fish samples were stored in refrigerator at $4{ }^{\circ} \mathrm{C} \pm 1$ and were visually inspected daily for signs of mold development and the rejection of samples were based on the visual observation of mold growth. 
1. Physical and chemical analysis:

1. 1. Chemical composition:

Moisture, protein and ash contents were determined according to the described methods of A.O.A.C. (1996), and fat content was determined as described by Blight and Dyer, (1959).

2. 1. Total volatile basis nitrogen (TVBN) and Trimethyleamine:

The total volatile basis nitrogen and trimethyleamine contents were determined according to the method of AMC (1979).

3. 1. Thiobarbituric acid (TBA):

Thiobarbituric acid was determined according to the method described by Tarladgis et al., ( 1960).

4. 1. $\mathrm{pH}$ value:

The $\mathrm{pH}$ was assessed using a $\mathrm{pH}$ meter as described by Carballo, et al., (1995).

2. Microbiological examination

2. 1. Total bacterial count and psychrophilic bacteria:

Total bacterial count (TBC); and Psychrophilic bacteria were determined as recommended by the APHA (1992) using plate count agar medium.

2. 2. Enterobacteriaceae:

The count of Enterobacteriaceae was determined on violet red bile dextrose agar medium after incubation at $37{ }^{\circ} \mathrm{C}$ for $20-24 \mathrm{~h}$ as described by Roberts,et al., (1995).

3. 2. Total Mold and yeast count:

Mold and yeast counts were determined as described by Oxoid Manual, (1982) using Oxytetracycline glucose yeast extracts agar (Oxoid CM 545) medium.

3. Sensory evaluation

Sensory evaluation including odor, texture and appearance were judged subjectively on fish samples by 10 members from The Food irradiation Laboratory, Plant Research Dept., Radioisotope Application Division; Nuclear Research Center, Abu Zaabal, Egypt using 5 point scoring system according to Aranda and Rodriguez (1970). Any sample failing to score 2.8 on any individual parameter was likewise discarded as follow:

\begin{tabular}{|c|c|}
\hline 5 & Excellent \\
\hline $4-5$ & fresh \\
\hline $2.8-4$ & acceptable \\
\hline$<2.8$ & rejected \\
\hline
\end{tabular}

\section{RESULTS AND DISCUSSION}

\section{Chemical composition of fish treatments}

Chemical composition of silver Carp fish used for this study was tabulated in table (1). It could be noticed that the moisture content of raw silver carp fish was $78.33 \%$ after salt treatment, the moisture content of fish was reduced to $71.05 \%$ this may be due to osmotic effect. The salted irradiated samples were the lowest in moisture content between the treatments. With regard to irradiation process only, a slightly effect on chemical composition of silver carp fish was observed, however, the salting and irradiation treatment (at 1, 2, 3 and $5 \mathrm{kGy}$ ) had a noticeable effect on 
Afifi, El. A. et al.

chemical composition (moisture, fat, protein and ash), this may be attributed to the loss in moisture owing to osmotic effect Scott, (1989) and Sofos, 1984.

Table (1): Chemical composition of silver carp fish as affected by salting and or different doses of gamma irradiation.

\begin{tabular}{|c|c|c|c|c|c|c|c|c|c|c|}
\hline \multirow{2}{*}{$\begin{array}{l}\text { Treatments } \\
\text { parameters }\end{array}$} & \multirow{2}{*}{\multicolumn{2}{|c|}{ Control salted }} & \multicolumn{8}{|c|}{ Doses (kGy) } \\
\hline & & & $1^{*}$ & 1 & $2^{*}$ & 2 & $3^{*}$ & 3 & $5^{\star}$ & 5 \\
\hline & 78.33 & 71.05 & 71.04 & 78.16 & 671.02 & $\begin{array}{l}77.98 \\
\end{array}$ & 71.00 & 77.59 & 770.93 & 77.00 \\
\hline Protein $^{\star \star}$ & 83.36 & 80.72 & 80.70 & 83.35 & 80.69 & 83.34 & 80.68 & 83.32 & 80.65 & 83.30 \\
\hline Fat $^{* \star}$ & 10.70 & 7.67 & 7.58 & 10.64 & \begin{tabular}{|l|l|}
4 & 7.48 \\
\end{tabular} & 10.60 & 7.32 & 10.58 & 7.18 & 10.41 \\
\hline $\mathrm{Ash}^{\star *}$ & 5.79 & 11.60 & 11.67 & 5.83 & 11.70 & 5.88 & 11.78 & 5.90 & 11.76 & 5.94 \\
\hline
\end{tabular}

Biochemical indices of freshness:

Changes in the biochemical indices of freshness namely TVBN, TMA and TBA contents of control and irradiated silver carp samples during cold storage are shown in Tables (2-4).Table (2) represents the total volatile bases nitrogen (TVBN) values of silver carp fish samples during the course of cold storage. The initial value of TVBN in the control samples was $9.12 \mathrm{mg}$ $\mathrm{N} / 100 \mathrm{gm}$ and this value was gradually increased which reached to 80.71 $\mathrm{mgN} / 100 \mathrm{gm}$ within 9 days of cold storage while that of salted silver carp fish was $9.11 \mathrm{mg} \mathrm{N} / 100 \mathrm{gm}$ at zero time and gradually increased reached to 60.42 $\mathrm{mg} \mathrm{N} / 100 \mathrm{gm}$ within 15 days of cold storage. On the other hand irradiation at $1,2,3$ and $5 \mathrm{kGy}$ suppressed the formation of TVBN during cold storage which reached to $46.89 ; 48.96 ; 40.00$ and $36.80 \mathrm{mg} \mathrm{N} / 100 \mathrm{gm}$ for unsalted and irradiated silver carp at 1,2,3 and 5 kGy within $21,27,30$ and 33 days, respectively while the TVBN values of salted silver carp irradiated at 1, 2, 3 and $5 \mathrm{kGy}$ reached $42.00,46.10,35.10$ and $30.10 \mathrm{mg} \mathrm{N} / 100 \mathrm{~g}$, respectively within 21, 27, 30 and $33 \mathrm{mg} \mathrm{N} / 100 \mathrm{gm}$.

Table (2): Effect of different doses of gamma irradiation and or dipping in $10 \%$ salt (Nacl) on Total Volatile Bases Nitrogen (TVBN) $\mathrm{mg} \mathrm{N} / 100 \mathrm{~g}$ of silver carp during cold storage at $4{ }^{\circ} \mathrm{C} \pm 1$.

\begin{tabular}{|c|c|c|c|c|c|c|c|c|c|c|}
\hline \multirow{2}{*}{$\begin{array}{c}\text { Treatments } \\
\text { Storage } \\
\text { Period (days) }\end{array}$} & \multirow[b]{2}{*}{ Contro } & \multirow[b]{2}{*}{ salted } & \multicolumn{8}{|c|}{ Doses (KGy) } \\
\hline & & & $1^{\star}$ & 1 & $2^{*}$ & 2 & $3^{*}$ & 3 & $5^{\star}$ & 5 \\
\hline 0 & 9.12 & 9.11 & 9.13 & 9.13 & 9.16 & 9.17 & 9.20 & 9.23 & 9.93 & 9.98 \\
\hline 3 & 27.21 & 17.73 & 10.88 & 11.92 & 10.00 & 10.00 & 9.42 & 9.50 & 9.99 & 10.00 \\
\hline 6 & 40.18 & 23.80 & 15.00 & 15.81 & 12.20 & 12.90 & 10.71 & 10.98 & 10.00 & 10.13 \\
\hline 9 & $80.71 \AA$ & 31.14 & 19.86 & 20.63 & 14.10 & 14.88 & 11.89 & 12.81 & 10.18 & 10.90 \\
\hline 12 & & 39.76 & 24.91 & 26.46 & 17.87 & 18.92 & 13.43 & 14.10 & 10.98 & 11.72 \\
\hline 15 & & $60.42 \AA$ & 30.80 & 33.89 & 19.10 & 20.81 & 16.32 & 17.79 & 11.23 & 12.10 \\
\hline 18 & & & 38.94 & 39.67 & 22.28 & 24.13 & 19.10 & 20.91 & 14.81 & 15.16 \\
\hline 21 & & & $42.00 \AA$ & $46.89 \AA$ & 27.44 & 29.20 & 23.00 & 24.77 & 19.13 & 19.90 \\
\hline 24 & & & & & 33.90 & 39.71 & 27.10 & 30.18 & 20.23 & 21.61 \\
\hline 27 & & & & & $46.10 \mathrm{~B}$ & $48.96 \AA$ & 30.20 & 36.30 & 22.34 & 23.80 \\
\hline 30 & & & & & & & $35.10 \AA$ & $40.00 \AA$ & 25.10 & 27.00 \\
\hline 33 & & & & & & & & & $30.10 \AA$ & $36.80 \AA$ \\
\hline
\end{tabular}


It could be noticed that the salted and irradiated treatments reduced the increasing rate of TVBN of sliver carp fish owing to the reduction of spoilage causing gram negative bacteria which are sensitive to irradiation (Lewis, et al., 1971) and also the bacteriostatic effect of salt is well known apart from its role in reduction of water activity, (Scott, 1989; Sofos, 1984).

Table (3) shows the effect of different doses of gamma irradiation and /or dipping in $10 \%$ salt on TMA of silver carp fish during cold storage. Data indicate that the TMA content of the control silver carp samples was gradually increased during the storage period which reached $12.42 \mathrm{mg} \mathrm{N} / 100 \mathrm{~g}$ after 12 days of cold storage whereas there was a reduction in the increasing rate of TMA after dipping in $10 \%$ salt solution which reached to $8.91 \mathrm{mg} \mathrm{N} / 100 \mathrm{gm}$ after 12 days for salted silver carp. Regarding to irradiation process it could be noticed that there was a slightly gradually increase in TMA according to irradiation doses specially with irradiated and salted silver carp samples as shown in Table (3). Spinelli,et al., (1969) related TMA content to irradiation dose and concluded that TMA is only useful as a quality index in fish irradiated below $1 \mathrm{kGy}$ because of the very small amount formed at higher doses. Laycock and Reigier (1970) proved that TMA production in irradiated fish is not only a function of the dose, but also of the preirradiation quality of the fish.

Table (3): Effect of different doses of gamma irradiation and or dipping in $10 \%$ salt $(\mathrm{NaCl})$ on Trimethyleamine (TMA) $\mathrm{mg} / 100 \mathrm{~g}$ of silver carp during cold storage at $4{ }^{\circ} \mathrm{C} \pm 1$.

\begin{tabular}{|c|c|c|c|c|c|c|c|c|c|c|}
\hline \multirow{2}{*}{$\begin{array}{c}\text { Treatments } \\
\begin{array}{c}\text { Storage period } \\
\text { (days) }\end{array}\end{array}$} & \multirow[b]{2}{*}{ Control } & \multirow[b]{2}{*}{ salted } & \multicolumn{8}{|c|}{ Doses (kGy) } \\
\hline & & & $1^{*}$ & 1 & $2^{*}$ & 2 & $3^{\star}$ & 3 & $5^{\star}$ & 5 \\
\hline 0 & 0.68 & 0.69 & 0.72 & 0.70 & 0.73 & 0.73 & 0.74 & 0.73 & 0.75 & 0.76 \\
\hline 3 & 2.99 & 1.20 & 0.90 & 0.88 & 0.78 & 0.80 & 0.78 & 0.79 & 0.77 & 0.78 \\
\hline 6 & 5.23 & 2.49 & 1.31 & 1.27 & 0.84 & 0.88 & 0.82 & 0.84 & 0.80 & 0.82 \\
\hline 9 & 8.88 & 4.31 & 1.90 & 1.86 & 0.90 & 0.89 & 0.89 & 0.92 & 0.83 & 0.86 \\
\hline 12 & $12.42 \AA$ & $8.91 \AA$ & 2.47 & 2.81 & 1.03 & 1.10 & 0.96 & 1.00 & 0.88 & 0.92 \\
\hline 15 & & & 3.00 & 3.10 & 1.20 & 1.24 & 1.10 & 1.09 & 0.95 & 0.98 \\
\hline 18 & & & 3.40 & 3.55 & 1.29 & 1.37 & 1.12 & 1.16 & 1.00 & 1.13 \\
\hline 21 & & & $4.82 \AA$ & $5.61 \AA$ & 1.38 & 1.42 & 1.20 & 1.30 & 1.08 & 1.20 \\
\hline 24 & & & & & 1.59 & 1.70 & 1.41 & 1.48 & 1.16 & 1.23 \\
\hline 27 & & & & & $2.42 \AA$ & $2.84 \AA$ & 1.95 & 1.96 & 1.29 & 1.29 \\
\hline 30 & & & & & & & $2.23 \AA$ & $2.37 \AA$ & 1.48 & 1.53 \\
\hline 33 & & & & & & & & & $1.80 \AA$ & $1.92 \AA$ \\
\hline
\end{tabular}

* Silver carp immersed in $10 \%$ salt and irradiated $\AA$ rejected on visual observed mold growth

TBA is widely used as indicator for the assessment of the degree of lipid oxidation. The extent of lipid oxidation in silver carp fish during cold storage is tabulated in Table (4).

It is clear that both irradiation and combination between irradiation and salting caused an increase in the TBA value during cold storage ( Table. 4) which the TBA value of the control and salted silver carp fish increased to $0.76,0.89 \mathrm{mg}$ malonaldehyde $/ \mathrm{kg}$ fish at 12 and 15 days of cold storage, respectively. Fish subjected to irradiation at 1,2, 3 and 5 kGy showed a 
Afifi, El. A. et al.

gradual increase in TBA value at the same time, TBA value of salted and irradiated fish were always higher than those of fish subjected to irradiation alone. This is presumably due to the influence of salt in enhancing of oxidative reactions in muscle foods (Kanner, et al., 1991). The results are in agreement with those of Chouliara et al., (2004).

Table (4): Effect of different doses of gamma irradiation and or dipping in $10 \%$ salt $(\mathrm{NaCl})$ on Thiobarbituric acid (TBA) $\mathrm{mg} / \mathrm{kg}$ of silver carp during cold storage at $4^{\circ} \mathrm{C} \pm 1$.

\begin{tabular}{|c|c|c|c|c|c|c|c|c|c|c|}
\hline \multirow{2}{*}{\begin{tabular}{|c|} 
Treatments \\
$\begin{array}{c}\text { Storage period } \\
\text { (days) }\end{array}$ \\
\end{tabular}} & \multirow{2}{*}{ Control } & \multirow{2}{*}{ salted } & \multicolumn{8}{|c|}{ Doses (kGy) } \\
\hline & & & $1^{*}$ & 1 & $2^{*}$ & 2 & $3^{*}$ & 3 & $5^{\star}$ & 5 \\
\hline 0 & 0.27 & 0.28 & 0.30 & 0.29 & 0.34 & 0.33 & 0.39 & 0.37 & 0.50 & 0.48 \\
\hline 3 & 0.39 & 0.42 & 0.46 & 0.44 & 0.55 & 0.56 & 0.60 & 0.58 & 0.64 & 0.62 \\
\hline 6 & 0.47 & 0.49 & 0.55 & 0.52 & 0.64 & 0.63 & 0.71 & 0.68 & 0.80 & 0.77 \\
\hline 9 & 0.59 & 0.63 & 0.66 & 0.64 & 0.72 & 0.74 & 0.86 & 0.80 & 0.98 & 0.90 \\
\hline 12 & $0.76 \AA$ & 0.78 & 0.83 & 0.80 & 0.90 & 0.89 & 0.94 & 0.92 & 1.10 & 1.00 \\
\hline 15 & & $0.89 \AA$ & 0.92 & 0.91 & 1.20 & 1.18 & 1.30 & 1.26 & 1.43 & 1.38 \\
\hline 18 & & & 1.09 & 1.00 & 1.43 & 1.30 & 1.48 & 1.46 & 1.50 & 1.49 \\
\hline 21 & & & $1.30 \AA$ & $1.20 \AA$ & 1.60 & 1.52 & 1.68 & 1.62 & 1.72 & 1.69 \\
\hline 24 & & & & & 1.83 & 1.77 & 1.88 & 1.80 & 1.94 & 1.88 \\
\hline 27 & & & & & $2.00 \AA$ & $1.94 \AA$ & 1.99 & 1.97 & 2.31 & 2.00 \\
\hline 30 & & & & & & & $2.43 \AA$ & $2.30 \AA$ & 2.88 & 2.31 \\
\hline 33 & & & & & & & & & $3.80 \AA$ & $3.62 \AA$ \\
\hline
\end{tabular}

Data presented in Table (5) represent the $\mathrm{pH}$ values of the Silver Carp fish samples either (control) or immersed in $10 \%$ salt and treated with various doses of gamma irradiation. It could be noticed that the $\mathrm{pH}$ values of the control silver carp fish samples were around 6.51 , while that salted was 6.42 at zero time of cold storage at $4{ }^{\circ} \mathrm{C} \pm 1$. Also, the $\mathrm{pH}$ values of salted irradiated (1, 2, 3 and $5 \mathrm{kGy}$ ) and irradiated samples (1,2,3 and $5 \mathrm{kGy})$ were $6.43 ; 6.44 ; 6.47 ; 6.50 ; 6.55 ; 6.56$ and 6.58 respectively.

Generally, no significantly differences were observed between all treatments at the beginning of storage. These results are in agreement with those obtained by Shawki, (1998). However, during cold storage, the $\mathrm{pH}$ value was slightly increased for all treatments under refrigeration and reached to 7.13 and 6.94 for control and salted silver carp fish at the end of storage being 9 and 15 days respectively. Meanwhile, the $\mathrm{pH}$ values of salted irradiated and irradiated at $(1,2,3$ and $5 \mathrm{kGy})$ silver carp fish reached to 6.78 , $6.80,6.70,6.70,6.86,6.93,6.76$ and 6.77 during cold storage at 21, 27, 30 and 33 days, respectively. The increase in the $\mathrm{pH}$ value might be due to the action of bacteria and tissue enzymes of fish proteins and production of ammonia and amines. Licciardello, et al., (1984) reported that $\mathrm{pH}$ value between 6.7 and 7.1 for non irradiated, sorbate/irradiated cod fillets over a 27-day post irradiation storage period in ice. These results are in accordance in those of Hammad, et al., (1995); Shawki,(1998) and El-Hanafy (2001). 
Table (5): Effect of different doses of gamma irradiation and or dipping in $10 \%$ salt $(\mathrm{NaCl})$ on $\mathrm{pH}$ of silver carp during cold storage at $4^{\circ} \mathrm{C} \pm 1$.

\begin{tabular}{|c|c|c|c|c|c|c|c|c|c|c|}
\hline Treatments & \multirow{2}{*}{ Control } & \multirow{2}{*}{ salted } & \multicolumn{8}{|c|}{ Doses (KGy) } \\
\hline Storage period(days) & & & $1^{*}$ & 1 & $2^{\star}$ & 2 & $3^{*}$ & 3 & $5^{\star}$ & 5 \\
\hline 0 & 6.51 & 6.42 & 6.43 & 6.50 & 6.44 & 6.55 & 6.47 & 6.56 & 6.50 & 6.58 \\
\hline 3 & 6.76 & 6.48 & 6.50 & 6.56 & 6.46 & 6.55 & 6.49 & 6.57 & 6.57 & 6.58 \\
\hline 6 & 6.92 & 6.60 & 6.59 & 6.59 & 6.50 & 6.58 & 6.48 & 6.57 & 6.59 & 6.59 \\
\hline 9 & $7.13 \AA$ & 6.76 & 6.61 & 6.64 & 6.53 & 6.60 & 6.50 & 6.58 & 6.60 & 6.59 \\
\hline 12 & & 6.87 & 6.64 & 6.70 & 6.55 & 6.62 & 6.52 & 6.58 & 6.60 & 6.61 \\
\hline 15 & & $6.94 \AA$ & 6.70 & 6.76 & 6.60 & 6.65 & 6.56 & 6.60 & 6.59 & 6.63 \\
\hline 18 & & & 6.74 & 6.80 & 6.68 & 6.73 & 6.60 & 6.66 & 6.62 & 6.66 \\
\hline 21 & & & $6.78 \AA$ & $6.86 \AA$ & 6.72 & 6.81 & 6.63 & 6.67 & 6.64 & 6.68 \\
\hline 24 & & & & & 6.77 & 6.86 & 6.65 & 6.69 & 6.65 & 6.67 \\
\hline 27 & & & & & $6.80 \AA$ & $6.93 \AA$ & 6.67 & 6.71 & 6.66 & 6.69 \\
\hline 30 & & & & & & & $6.70 \AA$ & $6.76 \circledast$ & 6.66 & 6.70 \\
\hline 33 & & & & & & & & & $6.70 \AA$ & $6.77 \AA$ \\
\hline
\end{tabular}

* Silver carp immersed in $\mathbf{1 0} \%$ salt and irradiated

$\AA$ rejected on visual observed mold growth

\section{Microbiological analyses:}

The effect of different doses of gamma irradiation and/or dipping in $10 \%$ salt on TBC of silver carp during cold storage was shown in Table (6). Data indicate that the initial total bacterial count of silver carp (control) was $3.9 \times 10^{5} \mathrm{cfu} / \mathrm{g}$ and was increased during cold storage $\left(8.1 \times 10^{7} \mathrm{cfu} / \mathrm{g}\right)$ at 6 days of cold storage at this period the sample was rejected according to ICMSF (1978) which stated that maximum acceptable count for fresh water fish is $10^{7} \mathrm{cfu} / \mathrm{g}$.

Where as after dipping in $10 \%$ salt the initial total bacterial count was $3.7 \times 10^{5}$ and there was an increase during the storage period reached to $8.9 \times 10^{7}$ at 12 days of cold storage at this point the samples were rejected according to ICMSF (1978).

According to the irradiation doses it could be observed that after irradiation with different doses there was a decrement in the TBC especially at higher doses, which reached to $4.0 \times 10$ at zero time for samples irradiated with $5 \mathrm{kGy}$ without salting. These results are in good coincide with those obtained by Venugopal, et al., (1999).

On the other hand the TBC of samples which were immersed in $10 \%$ salt before irradiation was lower at zero time comparing with the other treatments which was $3.7 \times 10$ for salted and irradiated samples with $5 \mathrm{kGy}$ at zero time of cold storage period. There was an increase in TBC of all samples during the course of cold storage and there was no differences in the shelf life between the samples (irradiated and salted with irradiated) at the same dose which were $1.2 \times 10^{6}$ and $4.5 \times 10^{6} \mathrm{cfu} / \mathrm{g}$ at the day 33 of cold storage for the salted-irradiated and irradiated at $5 \mathrm{kGy}$, respectively. It could be noticed that the TBC of the salted irradiated samples were lower than the samples of other treatments according to Fu, et al., (1995) who observed a sensitizing effect of salt on irradiation induced reduction of total plate count including pathogens in cooked pork chops and cured ham.

The total psychrophilic count for different treatments of silver carp fish under refrigeration were given in Table (7). 
Afifi, El. A. et al.

6

10200 
J. Agric. Sci. Mansoura Univ., 32 (12), December, 2007

7

10201 
Afifi, El. A. et al.

It is clear that the combined use of salting and irradiation at 1,2, 3 and $5 \mathrm{kGy}$ resulted in psychrophilic count that was lower than those of the control, salted and irradiated samples. Initial psychrophilic counts for control and salted samples were $3.7 \times 10^{3}$ and $3.2 \times 10^{3} \mathrm{cfu} / \mathrm{g}$ where as the respective counts in salted samples and irradiated at 1,2, 3 and $5 \mathrm{kGy}$ were $1.2 \times 10^{2}, 7.1 \times 10$, $3.1 \times 10$ and $<10$ at zero time of refrigerated storage. On the other hand the initial psychrophilic counts of samples irradiated at 1,2,3 and $5 \mathrm{kGy}$ were 2.3 $\times 10^{2}, 8.5 \times 10,4.6 \times 10$ and $<10 \mathrm{cfu} / \mathrm{g}$, respectively. Total psychrophilic counts for control and salted silver carp fish reached to $2.3 \times 10^{6}$ and $3.5 \times 10^{6}$ after 9 and 15 days of cold storage, respectively. From the same data it is clear that irradiation at $1,2,3$ and $5 \mathrm{kGy}$ reduced the population of psychrophilic bacteria specially in salted samples which reached to $1.9 \times 10^{5}, 6.1 \times 10^{4}$, $1.1 \times 10^{4}$ and $1.8 \times 10^{3} \mathrm{cfu} / \mathrm{g}$ for salted samples irradiated at $1,2,3$ and $5 \mathrm{KGy}$ after $21,24,30$ and 33 days of cold storage, respectively, whereas it reached to $3.6 \times 10^{5}, 7.3 \times 10^{4}, 2.4 \times 10^{4}$ and $8.7 \times 10^{3} \mathrm{cfu} / \mathrm{g}$ after the same periods for irradiated samples at 1, 2, 3 and $5 \mathrm{kGy}$. It is clear that the irradiation process reduced the counts of psychrophilic especially at the highest dose (5 kGy) which were undectable at zero time and till 6 days of cold storage.

It is obvious that combination of salt and irradiation with different doses reduced the counts of psychrophilic as compared with the use of irradiation only. These results are in agree with Chouliara, et,al.,(2004), who showed that irradiation affected populations of bacteria, namely, Pseudomonas spp., $\mathrm{H}_{2} \mathrm{~S}$-producing bacteria, Brochothrix thermosphacta, Enterobacteriaceae and Lactic acid bacteria otherwise the salt acts bacteriostatically through the reduction of water activity as well as by improving texture of the products (Sofos, 1984).

Enterobacteriaceae (Table 8) were also part of the tested microflora for silver carp fish. The contribution of Enterobacteriaceae to the microflora of fish and its spoilage potential must be taken into consideration especially in the case of polluted water or delay in chilling after catch (Lindberg, et al., 1998).

The data showed that the initial count of Enterobacteriacea for control and salted silver carp fish samples were $8.1 \times 10$ and $8.0 \times 10$, respectively and were slightly increased during the course of cold storage reached to $9.1 \times 10^{2}$ and $8.9 \times 10^{2} \mathrm{cfu} / \mathrm{g}$ at 9 days of cold storage. It is clear that the enterobacteriacea count of irradiated samples both salted and unsalted were undectable at zero time and during the whole period of cold storage except the samples irradiated $1 \mathrm{KGy}$, which was $4.2 \times 10 \mathrm{cfu} / \mathrm{g}$ at zero time of cold storage and slightly increase during the storage period reached to $9.3 \times 10$ at the day 21 of cold storage. Fu, et al., (1995) indicated that salt enhanced radiation-induced elimination of Listeria monocytogenes and Salmonella typhimurium in some red meat products. Also Ingram and Kitchell, (1967) reported that the role of salt in improving texture and flavor of food products is known that it is a part from its bacteriostatic effect. These results are in agree with those of Chouliara, et al (2004). 
Table (8): Effect of different doses of gamma irradiation and or dipping in $10 \%$ salt $(\mathrm{NaCl})$ on Enterobacteraceae $(\mathrm{cfu} / \mathrm{g})$ of silver carp during cold storage at $4{ }^{\circ} \mathrm{C} \pm 1$.

\begin{tabular}{|c|c|c|c|c|c|c|c|c|c|c|}
\hline Treatments & Control & salted & \multicolumn{8}{|c|}{ Doses (KGy) } \\
\hline $\begin{array}{c}\text { Storage period } \\
\text { (days) }\end{array}$ & & & $1^{*}$ & 1 & $2^{*}$ & 2 & $3^{*}$ & 3 & $5^{\star}$ & 5 \\
\hline 0 & $8.1 \times 10$ & $8.0 \times 10$ & --- & $4.2 \times 10$ & --- & --- & --- & --- & --- & --- \\
\hline 3 & $9.2 \times 10$ & $8.7 \times 10$ & --- & $5.0 \times 10$ & --- & --- & --- & --- & --- & --- \\
\hline 6 & $3.2 \times 10^{2}$ & $2.4 \times 10^{2}$ & --- & $6.2 \times 10$ & --- & --- & --- & --- & --- & --- \\
\hline 9 & $9.1 \times 10^{2} \AA$ & $8.9 \times 10^{2} \AA$ & --- & $6.8 \times 10$ & --- & --- & --- & --- & --- & --- \\
\hline 12 & & & --- & $7.2 \times 10$ & --- & --- & --- & --- & --- & --- \\
\hline 15 & & & --- & $7.8 \times 10$ & --- & --- & --- & --- & --- & --- \\
\hline 18 & & & --- & $8.1 \times 10$ & --- & --- & --- & --- & --- & --- \\
\hline 21 & & & $---(\AA)$ & $9.3 \times 10 \AA$ & --- & --- & --- & --- & --- & --- \\
\hline 24 & & & & & $\mid--(\AA$ & $--(\AA)$ & --- & --- & --- & --- \\
\hline 27 & & & & & & & --- & --- & --- & --- \\
\hline 30 & & & & & & & $-\cdots(\AA)$ & \begin{tabular}{|l|l}
---( \\
\end{tabular} & --- & --- \\
\hline 33 & & & & & & & & & $---\circledast$ & $---\circledast$ \\
\hline
\end{tabular}

${ }^{*}$ Silver carp immersed in $\mathbf{1 0} \%$ salt and irradiated

--- No growth

$\AA$ rejected on visual observed mold growth

Table (9) represents mold and yeast count of silver carp fish samples.It could be noticed that the initial count of control and salted samples were $8.1 \times 10^{2}$ and $8.0 \times 10^{2} \mathrm{cfu} / \mathrm{g}$, respectively, it took 9 and 15 days for the control and salted samples respectively, reached to the upper limit of total mold and yeast, at this stage the samples were rejected because of the growth of mold spots on the surface of the samples

With regard to salted irradiation and or salting it could be noticed that irradiation process reduced the count of mold and yeast for silver carp fish samples. At zero time especially at 2, 3 and $5 \mathrm{kGy}$ mold and yeast were undetectable at zero time for both irradiated and combined samples. Meanwhile, the count was slightly increased during cold storage for all treatments while the mold and yeast count of the salt irradiated treatment at different doses were slightly lower than that of the irradiated samples.

The combination of low-dose irradiation and salting apart from being beneficial for the shelf life extension of fishery products (Venugopal et al., 1999) has an additional advantage of elimination of several non sporeforming pathogens such as Listeria, Vibrio, and Salmonella spp. Which have low $D_{10}$ and thus inactivated at low doses of gamma irradiation (Radomyski, et al., 1994). At the same time, salt acts bacteriostatically through the reduction of water activity as well as by improving texture of the product (Sofos, 1984).

\section{Sensory evaluation:}

Data in Table (10) show the mean values of sensory scores including appearance, odor and texture of silver carp fish samples. It is obvious that the control samples were completely rejected by the panelists after 9 days due to the putrefaction smell and flabby texture, while dipping silver carp fish in salt solution prolonged the shelf-life of the samples to 12 days during cold storage. 
Afifi, El. A. et al.

9

10204 
J. Agric. Sci. Mansoura Univ., 32 (12), December, 2007

10

10205 
Afifi, El. A. et al.

This may be due to bacteriostatically effect of the salt through the reduction of water activity as well as by improving texture of the products (Sofos, 1984).

Application of gamma irradiation (1,2,3 and 5 kGy) slightly affect the scores of silver carp fish, since the mean value of sensory scores of samples soaked in salt solution was 4.7 while their value were 4.6, 4.6, 4.5 and 4.3 after exposure to 1,2,3 and $5 \mathrm{kGy}$ (Table 10). On the other hand after 21, 27, 30 and 33 days of cold storage, fungi spots appeared on the surface of irradiated silver carp fish samples. These samples were rejected by the panelists due to the appearance of mold although the odor and texture of the samples were still in a quite good condition.

It could be concluded that low dose irradiation at $3 \mathrm{kGy}$ can improve the hygienic quality of silver carp fish and enhance shelf life. Dipping in salt solution $(10 \% \mathrm{NaCl})$ prior to irradiation did not have any additional advantage in the shelf life extension of fish by irradiation, other benefits were noted such as: enhanced irradiation-induced elimination of the evaluated microorganisms; improved fish texture during cold storage.

\section{REFERENCES}

AMC (1979). Analytical Method Committee. Recommended ,method for the examination of fish and fish products. Analyst, 104, 434.

A.O.A.C. (1996). Official methods of analysis "Association of official analytic chemists", 16 th Ed Virginia, USA.

APHA (1992). Standard Methods for the Examination of Dairy Products, 14th Ed., American Public Health Association, Washington D.C.

Aranda, M.J.I and Rodriguez, M.A.A., (1970). Preservation of fish by irradiation. P.105, IAEA., fish (Lates calcarifer). J. Food Protec. 66, 410-417.

Blight, E.G., and Dyer, W.J., (1959). A rapid method of total lipid extraction and purification. Canadian Journal of Biochemistry and Physiology, 37, 911-917.

Carballo, J.; Moto, N.; Barreto, G. and Jimenez Colmenero, F. (1995). Binding properties and color of Bologna sausage made with varying fat levels, protein levels and cooking temperatures. Meat Sci. 41: 301.

Chouliara, I., Savvaidis, N. Panagiotakis and Kontominas, M.G., (2004). Preservation of salted, vacuum-packaged, refrigerated sea bream (Sparus aurata) fillets by irradiation: microbiological, chemical and sensory attributes. Food Microbiology,21:351-359.

El-Hanafy, Amira, E., A., (2001). Technological and chemical studies on fish and fishery products. PhD. Thesis, Food Science Dept., Faculty of Agriculture, Zagazig University.

Fu, A. H.; Sebranck, J.G., and Murano, E. A., (1995). Survival of Listeria monocytogenes and Salmonella typhimurium and quality attributes of cooked pork chops and cured ham after irradiation. Journal of Food Science, 60, 1001-1008. 
Garrett, E.S.; Jahncke, M.L. and Tennyson, J.M. (1997). Microbiological hazards and food safety issues associated with seafood. Journal of Food Protection, 60, 1409-1415.

Gram, L., and Huss, H.H. (1996). Microbiological spoilage of fish and fish products. International Journal of Food Microbiology, 33, 121-137.

Hammad, A. A. i.; A. El-A. Nassef and T. M. El-Mongy, (1995). Microbiological, chemical and sensory changes during storage of irradiated smoked mackerel. Egypt. J. Rad. Sci. Appl. 8, (2):. 225-235.

IAEA. (1989). Radiation preservation of fishery products. Technical report series 303. Vienna, International Atomic Energy Agency.

Icekson, I., Pasteur, R., Drabkin, V., Lapidot, M., Eizenberg, E., Klinger, I., Gelman, A., (1996). Prolonging shelf life of carp by combined ionizing radiation and refrigeration. J. Sci. Food Agric. 72, 353-358.

ICMSF (1978). International Commission on Microbiological Specification for Food. Sampling plans for fish and fishery products. In: ICMSF, Microorganisms in Foods. Sampling for microbiological analysis. Principles and Scientific Applications, $2^{\text {nd }}$ Edition, Vol. 2. Univ. Toronto Press, Toronto, Canada.

Ingram, M., and Kitchell, A. G. (1967 ). Salt as a preservative for foods. Journal of food Technology, 21, 1-5.

Kanner, J., Harel, S., and Jaffe, R. (1991). Lipid peroxidation of muscle food as affected by NaCL. Journal of Agricultural and Food Chemistry, 39, 1017-1021.

Laycock, A., and Reigier, L.W., (1970). The effect of gamma irradiation on the microbial spoilage pattern on fish in relation to initial quality. In: Preservation of fish by irradiation, International Atomic Energy Agency, Vienna, pp. 13-25.

Leistner, L., and Gorris, L.G.M. (1995). Food preservation by hurdle technology. Trends in Food Science and Technology, 6, 41-46.

Lewis, N.F., Alur, M.D., and Kumta, U.S., (1971). Radiation sensitivity of fish microflora, Indian Journal of Experimental Biology, 9, 45-49.

Licciardello, J.J., Ravesi, E.M., Tuhkunen, B.E., Racicot, L.D., (1984). Effect of some potentially synergistic treatments in combination with $100 \mathrm{Krad}$ irradiation on the iced shelf life of cod fillets. J. Food Sci. 49, 13411346, 1375.

Lindberg, A.M., Ljungh, A., Ahrne, S., Lodfhahl, S., Molin, G., (1998). Enterobacteriaceae found in high numbers in fish, minced meat and pasteurized milk or cream and the presence of toxin encoding genes. J. Food Microbiology. 39, 11-17.

Oxoid Manual (1982). The Oxoid manual of culture media, Ingredients and other laboratory services. Oxoid limited, Hampshire, England 5th ed.

Radomyski, T., Murano, E.A., Olson, D.G., Murano, P.S. (1994). Elimination of pathogens of significance in food by low-dose irradiation: a review. J. Food Prot. 57, 73-86.

Regenstein, J.M., Jauregui, C.A., and Baker, R.C. (1984). The effect of pH, polyphosphates and different salts on water retention properties of ground trout muscle. Journal of Food Biochemistry, 8, 123-131. 
Afifi, El. A. et al.

Roberts, D.; William, H. and Melody, G. (1995). Practical Food Microbiology. PHLS, London.

Scott, V.N., (1989). Interaction of factors to control microbial spoilage of refrigerated foods. Journal of Food Protection, 52, 431-435.

Shawki, H.A. (1998). Influence of ionizing radiation on fish products. M.sci. Dept. of Food Sci., Agri. Faculty, Zagazig Univ.

Sofos, J.N., (1984). Antimicrobial effects of sodium and other ions in foods. A review. Journal of Food Safety, 6, 45-78.

Spinelli J., Pelroy, G., Miyauchi, D., (1969) quality indices that can be used to assess irradiated seafood. In Kreuzer, R. (ed.), freezing and irradiation of fish. Fishing. New Books Limited, London, pp. 425-435.

Tarladgis, B.G.; Watts, B.M. and Younatchan (1960). A distillation method for the quantitative determination of malonaldehyde in rancid foods. J. Am. Oil Chem. Soc., 37(1): 44-48.

Venugopal, V., Doke, S.N and Thomas, P.(1999). Radiation processing to improve the quality of fishery of fishery products. Critical Reviews in Food Science and Nutrition, 39, 391-440.

WHO, (1994). Wholesomeness of Irradiated Food. Geneva: World Health Organization.

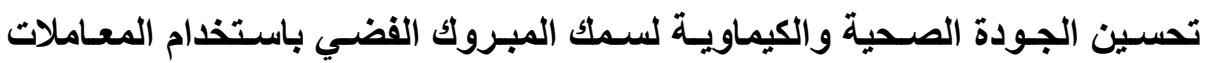

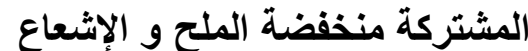

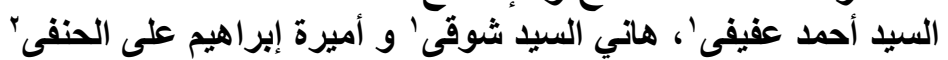
ا مركز البحوث النوويةـ هيئة الطاقة الذرية. r r المعمل المركزي لبحوث الثروة السمكيةـ مركز البحوث الزراعية.

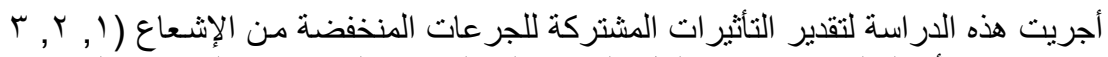

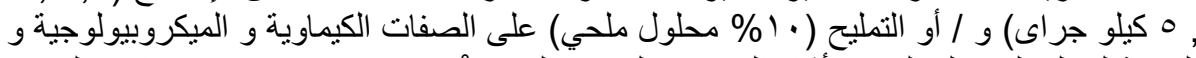

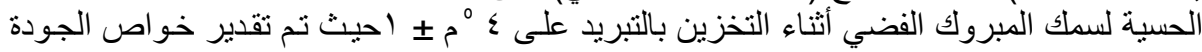

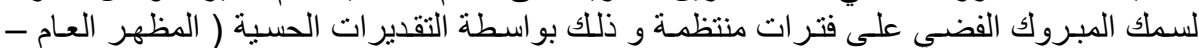

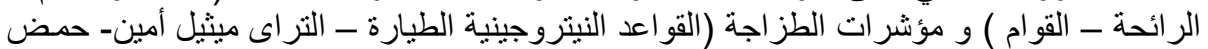

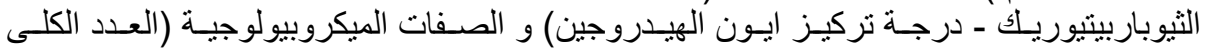

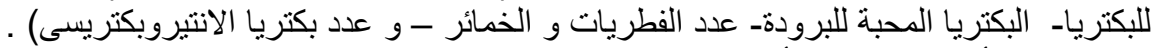

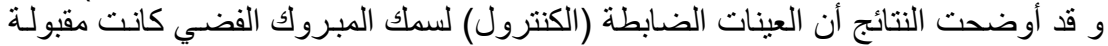

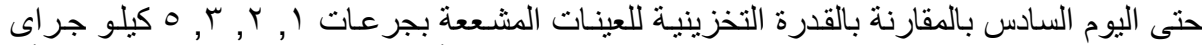

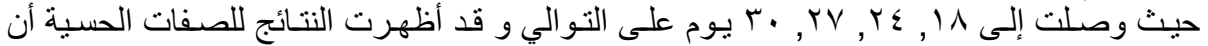
استخدام التمليح (• ( \% محلول ملحي) أعطى قوام متماسك لسمك المبروك أثنـاء فترة التخزين بالتبريد.

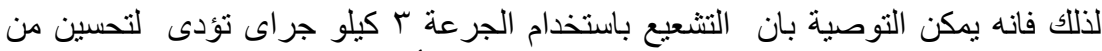

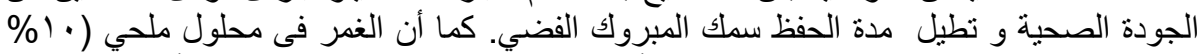

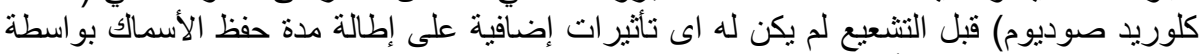

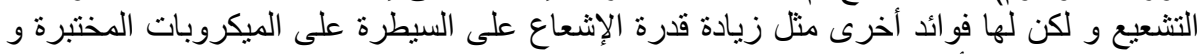
كذلك تحسين القو ام أثناء التخزين بالتبريد. 
J. Agric. Sci. Mansoura Univ., 32 (12): 10193 - 10208, 2007

Table (6): Effect of different doses of gamma irradiation and or dipping in $10 \%$ salt (Nacl) on the total bacterial count (TBC) (cfu/g) of silver carp during cold storage at $4^{\circ} \mathrm{C} \pm 1$.

\begin{tabular}{|c|c|c|c|c|c|c|c|c|c|c|}
\hline \multirow{2}{*}{$\begin{array}{c}\text { Treatments } \\
\text { Storage period } \\
\text { (days) }\end{array}$} & \multirow[b]{2}{*}{ Control } & \multirow[b]{2}{*}{ salted } & \multicolumn{8}{|c|}{ Doses (KGy) } \\
\hline & & & $1^{*}$ & 1 & $2^{*}$ & 2 & $3^{*}$ & 3 & $5^{\star}$ & 5 \\
\hline 0 & $3.9 \times 10^{5}$ & $3.7 \times 10^{5}$ & $4.2 \times 10^{4}$ & $4.6 \times 10^{4}$ & $3.0 \times 10^{3}$ & $3.6 \times 10^{3}$ & $5.3 \times 10^{2}$ & $6.0 \times 10^{2}$ & $3.7 \times 10$ & $4.0 \times 10$ \\
\hline 3 & $3.9 \times 10^{6}$ & $4.3 \times 10^{5}$ & $6.9 \times 10^{4}$ & $7.8 \times 10^{4}$ & $3.7 \times 10^{3}$ & $4.9 \times 10^{3}$ & $5.5 \times 10^{2}$ & $6.8 \times 10^{2}$ & $4.1 \times 10$ & $7.3 \times 10^{2}$ \\
\hline 6 & $8.1 \times 10^{7}$ & $7.1 \times 10^{6}$ & $8.2 \times 10^{4}$ & $9.9 \times 10^{4}$ & $4.8 \times 10^{3}$ & $8.3 \times 10^{3}$ & $7.3 \times 10^{2}$ & $8.1 \times 10^{2}$ & $8.8 \times 10$ & $9.8 \times 10^{2}$ \\
\hline 9 & $7.8 \times 10^{8} \AA$ & $9.3 \times 10^{6}$ & $1.9 \times 10^{5}$ & $2.9 \times 10^{5}$ & $9.2 \times 10^{3}$ & $1.8 \times 10^{4}$ & $9.2 \times 10^{2}$ & $1.7 \times 10^{3}$ & $3.0 \times 10$ & $9.0 \times 10^{2}$ \\
\hline 12 & & $8.9 \times 10^{7}$ & $3.7 \times 10^{5}$ & $5.5 \times 10^{5}$ & $9.8 \times 10^{3}$ & $2.9 \times 10^{4}$ & $2.3 \times 10^{3}$ & $7.2 \times 10^{3}$ & $4.1 \times 10^{2}$ & $7.2 \times 10^{2}$ \\
\hline 15 & & $8.1 \times 10^{8} \circledast$ & $8.1 \times 10^{6}$ & $8.7 \times 10^{6}$ & $1.0 \times 10^{4}$ & $4.7 \times 10^{4}$ & $4.8 \times 10^{3}$ & $9.1 \times 10^{3}$ & $5.2 \times 10^{2}$ & $8.3 \times 10^{2}$ \\
\hline 18 & & & $9.3 \times 10^{6}$ & $9.8 \times 10^{6}$ & $8.3 \times 10^{4}$ & $5.6 \times 10^{5}$ & $8.3 \times 10^{3}$ & $7.1 \times 10^{4}$ & $6.1 \times 10^{2}$ & $9.2 \times 10^{2}$ \\
\hline 21 & & & $4.3 \times 10^{7} \mathbb{B}$ & $8.1 \times 10^{7} \circledast$ & $9.7 \times 10^{5}$ & $8.8 \times 10^{6}$ & $3.2 \times 10^{4}$ & $2.3 \times 10^{5}$ & $8.8 \times 10^{2}$ & $1.8 \times 10^{3}$ \\
\hline 24 & & & & & $7.8 \times 10^{6}$ & $9.3 \times 10^{6}$ & $6.6 \times 10^{4}$ & $8.9 \times 10^{5}$ & $9.7 \times 10^{3}$ & $9.7 \times 10^{4}$ \\
\hline 27 & & & & & $8.2 \times 10^{6} \AA$ & $9.9 \times 10^{6} \AA$ & $4.3 \times 10^{5}$ & $1.3 \times 10^{6}$ & $3.6 \times 10^{4}$ & $8.1 \times 10^{5}$ \\
\hline 30 & & & & & & & $9.4 \times 10^{5} \AA$ & $6.7 \times 10^{6} \AA$ & $6.9 \times 10^{5}$ & $2.3 \times 10^{6}$ \\
\hline 33 & & & & & & & & & $1.2 \times 10^{6} \AA$ & $4.5 \times 10^{6} \AA$ \\
\hline
\end{tabular}

* silver carp immersed in $\mathbf{1 0 \%}$ salt and irradiated

$\AA$ rejected on visual observed mold growth 
Afifi, El. A. et al.

Table (7): Effect of different doses of gamma irradiation and or dipping in 10\% salt (Nacl) on Psychrophilic bacteria (cfu/g) of silver carp during cold storage at $4{ }^{\circ} \mathrm{C} \pm 1$.

\begin{tabular}{|c|c|c|c|c|c|c|c|c|c|c|}
\hline \multirow{2}{*}{$\begin{array}{c}\text { Treatments } \\
\text { Storage period } \\
\text { (days) }\end{array}$} & \multirow[b]{2}{*}{ Control } & \multirow[b]{2}{*}{ salted } & \multicolumn{8}{|c|}{ Doses (KGy) } \\
\hline & & & $1^{*}$ & 1 & $2^{*}$ & 2 & $3^{*}$ & 3 & $5^{\star}$ & 5 \\
\hline 0 & $3.7 \times 10^{3}$ & $3.2 \times 10^{3}$ & $1.2 \times 10^{2}$ & $2.3 \times 10^{2}$ & $7.1 \times 10$ & $8.5 \times 10$ & $3.1 \times 10$ & $4.6 \times 10$ & $<10$ & $<10$ \\
\hline 3 & $6.3 \times 10^{4}$ & $1.1 \times 10^{4}$ & $1.3 \times 10^{2}$ & $1.0 \times 10^{2}$ & $7.7 \times 10$ & $9.6 \times 10$ & $3.7 \times 10$ & $4.0 \times 10$ & $<10$ & $<10$ \\
\hline 6 & $4.7 \times 10^{5}$ & $6.9 \times 10^{4}$ & $2.7 \times 10^{2}$ & $1.9 \times 10^{2}$ & $8.1 \times 10$ & $9.9 \times 10$ & $4.9 \times 10$ & $5.8 \times 10$ & $<10$ & $<10$ \\
\hline 9 & $2.3 \times 10^{6} \AA$ & $3.1 \times 10^{5}$ & $3.9 \times 10^{3}$ & $4.6 \times 10^{3}$ & $1.7 \times 10^{2}$ & $3.1 \times 10^{2}$ & $6.3 \times 10$ & $7.7 \times 10$ & $2.1 \times 10$ & $1.5 \times 10$ \\
\hline 12 & & $7.8 \times 10^{5}$ & $4.2 \times 10^{3}$ & $8.9 \times 10^{3}$ & $6.1 \times 10^{2}$ & $8.4 \times 10^{2}$ & $8.1 \times 10$ & $9.3 \times 10$ & $4.3 \times 10$ & $6.0 \times 10$ \\
\hline 15 & & $3.5 \times 10^{6} \AA$ & $1.5 \times 10^{4}$ & $2.6 \times 10^{4}$ & $1.9 \times 10^{3}$ & $2.7 \times 10^{3}$ & $2.3 \times 10^{2}$ & $4.1 \times 10^{2}$ & $5.6 \times 10$ & $7.7 \times 10$ \\
\hline 18 & & & $7.7 \times 10^{4}$ & $8.7 \times 10^{4}$ & $8.7 \times 10^{3}$ & $9.9 \times 10^{3}$ & $8.7 \times 10^{2}$ & $9.1 \times 10^{2}$ & $7.1 \times 10$ & $8.9 \times 10$ \\
\hline 21 & & & $1.9 \times 10^{5} \AA$ & $3.6 \times 10^{5} \AA$ & $2.1 \times 10^{4}$ & $4.6 \times 10^{4}$ & $3.1 \times 10^{3}$ & $6.1 \times 10^{3}$ & $2.1 \times 10^{2}$ & $4.4 \times 10^{2}$ \\
\hline 24 & & & & & $6.1 \times 10^{4}$ & $7.3 \times 10^{4}$ & $6.6 \times 10^{3}$ & $8.7 \times 10^{3}$ & $4.9 \times 10^{2}$ & $9.1 \times 10^{2}$ \\
\hline 27 & & & & & $2.1 \times 10^{5}$ & $6.9 \times 10^{5} \AA$ & $9.1 \times 10^{3}$ & $9.8 \times 10^{3}$ & $8.1 \times 10^{2}$ & $2.3 \times 10^{3}$ \\
\hline 30 & & & & & & & $1.1 \times 10^{4} \AA$ & $2.4 \times 10^{4} \AA$ & $9.7 \times 10^{2}$ & $4.9 \times 10^{3}$ \\
\hline 33 & & & & & & & & & $1.8 \times 10^{3} \AA$ & $8.7 \times 10^{3} \AA$ \\
\hline
\end{tabular}

* Silver carp immersed in $10 \%$ salt and irradiated

$\AA$ rejected on visual observed mold growth 
J. Agric. Sci. Mansoura Univ., 32 (12), December, 2007

Table (9): Effect of different doses of gamma irradiation and or dipping in $10 \%$ salt (Nacl) on mold and yeast count of silver carp during cold storage at $4{ }^{\circ} \mathrm{C} \pm 1$.

\begin{tabular}{|c|c|c|c|c|c|c|c|c|c|c|}
\hline \multirow{2}{*}{$\begin{array}{c}\text { Treatments } \\
\text { Storage period } \\
\text { (days) }\end{array}$} & \multirow{2}{*}{ Control } & \multirow{2}{*}{ salted } & \multicolumn{8}{|c|}{ Doses (KGy) } \\
\hline & & & $1^{*}$ & 1 & $2^{*}$ & 2 & $3^{*}$ & 3 & $5^{\star}$ & 5 \\
\hline 0 & $8.1 \times 10^{2}$ & $8.0 \times 10^{2}$ & $7.4 \times 10$ & $7.9 \times 10$ & $<10$ & $<10$ & $<10$ & $<10$ & $<10$ & $<10$ \\
\hline 3 & $9.3 \times 10^{2}$ & $8.2 \times 10^{2}$ & $7.6 \times 10$ & $8.2 \times 10$ & $<10$ & $<10$ & $<10$ & $<10$ & $<10$ & $<10$ \\
\hline 6 & $3.8 \times 10^{3}$ & $9.3 \times 10^{2}$ & $8.1 \times 10$ & $9.6 \times 10$ & $6.3 \times 10$ & $6.7 \times 10$ & $<10$ & $<10$ & $<10$ & $<10$ \\
\hline 9 & $9.6 \times 10^{3} \AA$ & $1.1 \times 10^{3}$ & $8.8 \times 10$ & $9.9 \times 10$ & $7.2 \times 10$ & $8.1 \times 10$ & $<10$ & $<10$ & $<10$ & $<10$ \\
\hline 12 & & $2.3 \times 10^{3}$ & $9.0 \times 10$ & $1.7 \times 10^{2}$ & $8.4 \times 10$ & $9.7 \times 10$ & $1.3 \times 10$ & $1.8 \times 10$ & $<10$ & $<10$ \\
\hline 15 & & $6.2 \times 10^{3} \AA$ & $1.5 \times 10^{2}$ & $3.6 \times 10^{2}$ & $1.6 \times 10^{2}$ & $2.0 \times 10^{2}$ & $2.0 \times 10$ & $2.6 \times 10$ & $<10$ & $<10$ \\
\hline 18 & & & $6.3 \times 10^{2}$ & $9.1 \times 10^{2}$ & $3.1 \times 10^{2}$ & $4.4 \times 10^{2}$ & $3.1 \times 10$ & $4.2 \times 10$ & $<10$ & $<10$ \\
\hline 21 & & & $1.4 \times 10^{3} \AA$ & $2.8 \times 10^{3} \AA$ & $4.9 \times 10^{2}$ & $5.6 \times 10^{2}$ & $4.6 \times 10$ & $8.6 \times 10$ & $<10$ & $<10$ \\
\hline 24 & & & & & $6.8 \times 10^{2}$ & $7.3 \times 10^{2}$ & $9.6 \times 10$ & $2.5 \times 10^{2}$ & $1.1 \times 10^{2}$ & $2.1 \times 10^{2}$ \\
\hline 27 & & & & & $8.3 \times 10^{2} \AA$ & $9.8 \times 10^{2} \AA$ & $2.6 \times 10^{2}$ & $4.6 \times 10^{2}$ & $2.0 \times 10^{2}$ & $3.2 \times 10^{2}$ \\
\hline 30 & & & & & & & $4.7 \times 10^{2} \AA$ & $6.1 \times 10^{2} \AA$ & $3.3 \times 10^{2}$ & $4.1 \times 10^{2}$ \\
\hline 33 & & & & & & & & & $4.6 \times 10^{2} \mathbb{B}$ & $5.1 \times 10^{2} \AA$ \\
\hline
\end{tabular}

* Silver carp immersed in $10 \%$ salt and irradiated

§ rejected on visual observed mold growth 
Afifi, El. A. et al.

Table (10): Effect of different doses of gamma irradiation and or dipping in $10 \%$ salt (Nacl) on sensory evaluation of silver carp during cold storage at $4^{\circ} \mathrm{C} \pm 1$.

\begin{tabular}{|c|c|c|c|c|c|c|c|c|c|c|c|c|c|c|c|c|c|c|c|c|c|c|c|c|c|c|c|c|c|c|}
\hline \multirow{3}{*}{ 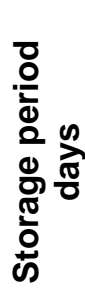 } & \multicolumn{3}{|c|}{ control } & \multicolumn{3}{|c|}{ salted } & \multicolumn{24}{|c|}{ Doses (KGy) } \\
\hline & \multirow[b]{2}{*}{ 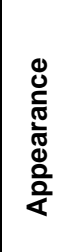 } & \multirow[b]{2}{*}{ 훙 } & \multirow[b]{2}{*}{ 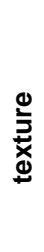 } & \multirow[b]{2}{*}{ 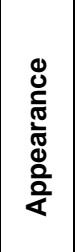 } & \multirow[b]{2}{*}{ 흠 } & \multirow[b]{2}{*}{ 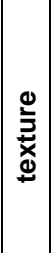 } & \multicolumn{3}{|c|}{$1^{*}$} & \multicolumn{3}{|c|}{1} & \multicolumn{3}{|c|}{$2^{\star}$} & \multicolumn{3}{|c|}{2} & \multicolumn{3}{|c|}{$3^{*}$} & \multicolumn{3}{|c|}{3} & \multicolumn{3}{|c|}{$5^{\star}$} & \multicolumn{3}{|c|}{5} \\
\hline & & & & & & & 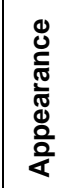 & 흉 & 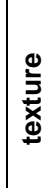 & 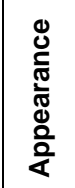 & ᄒे & 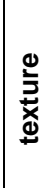 & $\begin{array}{l}0 \\
0 \\
\frac{0}{\pi} \\
\frac{\pi}{\pi} \\
\mathbb{0} \\
\frac{0}{0} \\
\frac{0}{4}\end{array}$ & 흥 & 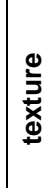 & 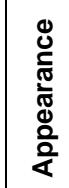 & 흥 & 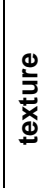 & 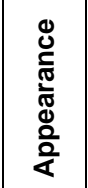 & 흠 & 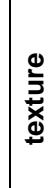 & 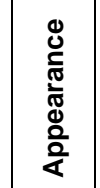 & 흥 & 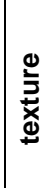 & 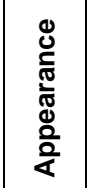 & 흥 & 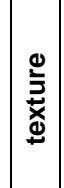 & 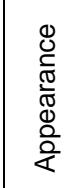 & & 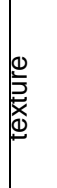 \\
\hline 0 & 4.8 & 4.7 & 4.7 & 4.8 & 4.7 & 4.7 & 4.7 & 4.6 & 4.6 & 4.6 & 4.5 & 4.4 & 4.7 & 4.5 & 4.6 & 4.5 & 4.4 & 4.3 & 4.6 & 4.4 & 4.5 & 4.4 & 4.2 & 4.2 & 4.5 & 4.3 & \begin{tabular}{|l|l|} 
& 4.3 \\
\end{tabular} & 4.2 & 4.0 & 4.0 \\
\hline 3 & 4.1 & 4.0 & 4.5 & 4.6 & 4.3 & 4.5 & 4.6 & 4.6 & 4.6 & 4.5 & 4.5 & 4.3 & 4.7 & 4.5 & 4.6 & 4.5 & 4.3 & 4.3 & 4.6 & 4.4 & 4.5 & 4.4 & 4.2 & 4.2 & 4.5 & 4.3 & 4.3 & 4.2 & 4.0 & 4.0 \\
\hline 6 & 3.0 & 2.9 & 3.7 & 4.2 & 4.0 & 4.1 & 4.6 & 4.5 & 4.6 & \begin{tabular}{|l|}
4.4 \\
\end{tabular} & 4.3 & 4.1 & 4.6 & 4.4 & 4.6 & 4.4 & 4.2 & 4.2 & 4.6 & 4.4 & 4.5 & 4.4 & 4.2 & 4.2 & 4.5 & 4.3 & 4.3 & 4.2 & 4.0 & 4.0 \\
\hline 9 & $2.1 \AA$ & 2.0 & 2.4 & 3.8 & 3.6 & 3.9 & 4.4 & 4.3 & 4.5 & 4.3 & 4.1 & 3.5 & 4.6 & 4.3 & 4.6 & 4.2 & 4.0 & 4.1 & 4.6 & 4.4 & 4.5 & 4.4 & 4.2 & 4.2 & 4.5 & 4.3 & 4.3 & 4.2 & 4.0 & 4.0 \\
\hline 12 & & & & 3.0 & 2.9 & 3.5 & 4.3 & 4.0 & 4.4 & 4.1 & 3.7 & 3.1 & 4.4 & 4.1 & 4.6 & 4.0 & 3.7 & 4.0 & 4.6 & 4.3 & 4.4 & \begin{tabular}{l|l}
4.4 \\
\end{tabular} & 4.1 & 4.1 & \begin{tabular}{|l|}
4.4 \\
\end{tabular} & 4.2 & 4.2 & 4.1 & 3.8 & 3.9 \\
\hline 15 & & & & $2.2 \AA$ & 2.6 & 2.9 & \begin{tabular}{|l|}
4.0 \\
\end{tabular} & 3.7 & 4.4 & \begin{tabular}{|l|}
3.4 \\
\end{tabular} & 3.0 & 2.9 & 4.3 & 4.1 & 4.5 & 3.5 & 3.5 & 4.0 & \begin{tabular}{|l|}
4.5 \\
\end{tabular} & 4.1 & 4.4 & 4.3 & 4.0 & 4.0 & 4.4 & 4.2 & 4.2 & 4.0 & 3.8 & 3.9 \\
\hline 18 & & & & & & & 3.2 & 3.0 & 3.9 & 3.0 & 2.8 & 2.8 & 4.0 & 3.7 & 4.2 & 3.5 & 3.3 & 3.7 & 4.5 & 4.0 & 4.3 & 4.3 & 3.8 & 3.7 & 4.3 & 4.2 & 4.1 & 4.0 & 3.6 & 3.8 \\
\hline 21 & & & & & & & $2.3 \AA$ & $2.6 \AA$ & 3.0 & $2.2 \AA$ & 2.6 & 2.5 & \begin{tabular}{|l|}
3.5 \\
\end{tabular} & 3.2 & 4.0 & 3.3 & 3.0 & 3.2 & 4.4 & 3.9 & 4.0 & 4.2 & 3.6 & 3.5 & 4.2 & 4.2 & 4.1 & 4.0 & 3.5 & 3.7 \\
\hline 24 & & & & & & & & & & & & & 3.0 & 3.0 & 3.1 & 3.0 & 2.9 & 3.0 & 4.2 & 3.6 & 3.9 & 4.0 & 3.3 & 3.3 & 4.0 & 4.1 & 4.0 & 3.9 & 3.4 & 3.7 \\
\hline 27 & & & & & & & & & & & & & $2.4 \AA$ & 2.8 & 2.8 & $2.3 \AA$ & 2.6 & 2.5 & \begin{tabular}{|l|}
4.0 \\
\end{tabular} & 3.2 & 3.4 & 3.5 & 3.0 & 2.9 & 3.9 & 3.9 & 4.0 & 3.7 & 3.3 & 3.6 \\
\hline 30 & & & & & & & & & & & & & & & & & & & $2.7 \AA$ & 3.0 & 3.0 & $2.4 \AA$ & 2.9 & 2.8 & \begin{tabular}{|l|}
3.2 \\
\end{tabular} & 3.4 & 3.3 & 3.0 & 3.0 & \\
\hline 33 & & & & & & & & & & & & & & & & & & & & & & & & & $2.7 \AA$ & 2.7 & 2.8 & $2.6 \AA$ & 2.5 & 2.6 \\
\hline
\end{tabular}

Drouth 